\title{
Liter per Nanomole per Second
}

National Cancer Institute

\section{Source}

National Cancer Institute. Liter per Nanomole per Second. NCI Thesaurus. Code C85692.

Liters per nanomole per second. 